\title{
Uma Pioneira: Maria Firmina dos Reis
}

\section{A Pioneer: Maria Firmina dos Reis}

\author{
Zahidé Lupinacci Muzart* \\ Universidade Federal de Santa Catarina
}

Qual é a cor de minha forma, do meu sentir? Qual é a cor da tempestade de dilacerações que me abala? Qual a de meus sonhos e gritos? Qual a de meus desejos e febre?

Cruz e Sousa, Emparedado ${ }^{1}$

Resumo: Nesse artigo analiso alguns aspectos da vida e da obra da escritora maranhense Maria Firmina dos Reis cujo livro Úrsula é dos primeiros publicados por uma mulher no Brasil. Destaco o fato de ter fundado uma escola mista para filhos de lavradores e a comparo com a escritora gaúcha Maria Josepha Barreto que, embora nascida no século XVIII, viveu e atuou politicamente no XIX. Analiso o romance Úrsula, primeiro romance abolicionista escrito por uma mulher negra.

Palavras-chave: Romance abolicionista. Úrsula. Maria Firmina dos Reis. Primeiros romances escritos por mulheres.

Abstract: In this article I analyze some aspects of life and work of the writer Maria Firmina dos Reis, born in Maranhão state, whose book Úrsula is one of the first to be published by a female writer in Brazil. I highlight the fact that she founded a school for sons and daughters of landsmen, and I compares her to Maria Josepha Barreto, born in the Rio Grande do Sul state, that, however born in the XVIII century, lived and acted politically in the XIX century. I analyze the book Úrsula, the first abolitionist novel written by a black woman.

Keywords: Abolitionist novel. Úrsula. Maria Firmina dos Reis. First novels written by women.

Antes da emergência, no século XX, dos movimentos literários negros, houve alguns precursores no Brasil do século XIX: os poetas negros João da Cruz e Souza (1861-1898) e Luis Gama (1830-1882) e também algumas mulheres: Auta de Souza (1876-1901), Luciana de Abreu (18471880) e Maria Firmina dos Reis (1825-1917).

O ano de 1859 é um marco na história do romance escrito por mulheres no Brasil, pois neste ano duas pioneiras publicam narrativas: a catarinense Ana Luisa de Azevedo Castro (1823?-1869) e a maranhense Maria Firmina dos Reis.

O romance de Maria Firmina é considerado o primeiro romance de autoria feminina no Brasil, mas, na verdade, os dois acima citados foram publicados no mesmo ano, sendo a primazia de Ana Luiza, pois em 1858
Neste artigo, utilizo informações já publicadas, principalmente no livro Escritoras brasileiras do século $X I X$, Florianópolis: Mulheres, 2000. (zmuzart@gmail.com)

${ }^{1}$ Poeta negro (18611898), nascido em Desterro, capital de Santa Catarina (atualmente, Florianópolis), é considerado o iniciador do Simbolismo no Brasil em 1893, com a publicação de Broquéis, poemas e Missal, poemas em prosa. Emparedado é um belíssimo texto de revolta contra a invisibilidade do negro no século XIX. Antes mesmo da publicação do famoso romance de Ralph Ellison, $O$ homem invisível, já um poeta brasileiro denunciava com notável acuidade o problema na sociedade brasileira. Este texto pertence à coletânea Evocações, de publicação póstuma, em 1898. 
já publicara sua narrativa em capítulos, em A Marmota, jornal do Rio de Janeiro, entre 13 de abril e 6 de julho de 1858. A autora, como tantas outras mulheres do século XIX, escondeu-se sob pseudônimo. Assinou com o curioso nome de Indígena do Ipiranga, tanto os capítulos do jornal quanto o livro em que os enfeixa no ano seguinte. Este pseudônimo já remete para a própria temática do romance, ligada ao indianismo. Maria Firmina dos Reis também prefere o pseudônimo. Uma Maranhense é o que usa para assinar o romance Úrsula. Os dois romances privilegiam em seus enredos a marginalização do outro: da mulher e do índio, no primeiro, D. Narcisa de Villar, e da mulher e do negro, em Úrsula.

A pesquisadora Luiza Lobo, autora de diversos estudos sobre Maria Firmina dos Reis e sua obra, afirma que D. Narcisa de Villar não é um romance, mas uma novela. A distinção, na literatura brasileira, entre romance e novela é muito tênue e, com relação aos dois romances, não permite a diferenciação. D. Narcisa de Villar é classificado como romance por outros ensaístas como Marisa Lajolo (2004, p.55).

Sobre a questão da prioridade, o estudioso Wilson Martins já havia assinalado, em sua monumental História da Inteligência brasileira, qual seria o primeiro romance publicado por uma brasileira:

O público feminino não era esquecido, com a Biblioteca das Mulheres, Moral e Divertida, de Bráulio Jaime Moniz Cordeiro (1829-?); no Maranhão, Maria Firmina dos Reis (1825-1881), autora, também, de A Escrava, publicou o romance Úrsula, apontado incorretamente como o primeiro do seu gênero escrito por mulher e impresso no Brasil (cf. Anais do Cenáculo Brasileiro de Letras e Artes, 1973, pp. 72 e s.). Antes dela [...], seria preciso considerar Nísia Floresta, com Daciz ou A Jovem Completa (1847) e Dedicação de uma Amiga (1850), ainda que excluíssemos da competição, aliás sem maior interesse, A Filósofa por Amor, de Eufrosina Barandas, no qual há páginas de ficção (1845), e a Lição a Meus Filhos (1854), de Ildefonsa Laura, que são dois contos em verso. (MARTINS, 1977, p.94).

Em 1850 é publicado em Niterói o romance histórico de Nísia Floresta, intitulado Dedicação de uma amiga, em dois volumes, trazendo apenas as iniciais B. A. como assinatura ${ }^{2}$. Este livro deve ser considerado o primeiro romance escrito por uma mulher no Brasil. As duas narrativas de Nísia Floresta, publicadas em 1847, no Rio de Janeiro - Daciz ou A jovem completa, Fany ou O modelo das donzelas - são pequenas e com objetivos muito didáticos e moralistas. E não podemos esquecer o romance de cunho político, Misterios del Plata, de Juana Paula Manso de Noronha, publicado no Jornal das Senhoras, por ela fundado em 1852. E, ao classificarmos Úrsula e D. Narcisa de Villar por sua organização, extensão, enredo completo, podemos afirmar que estão entre as primeiras publicadas no Brasil, com formato de romance propriamente.
${ }^{2}$ B. A. Dedicação de uma amiga. Niterói: Typographia Fluminense de Lopes e Cia, 1850. A pesquisadora Constância Lima Duarte (UFMG) enviou-nos uma cópia do primeiro volume, o único que encontrou. Deixamos registrado nosso sincero agradecimento pela generosidade. 
Maria Firmina dos Reis nasceu na Ilha de São Luís, MA, em 11 de outubro de 1825. Foi registrada como filha de João Pedro Esteves e Leonor Felipe dos Reis. Mulata e bastarda, Firmina é prima do escritor maranhense Sotero dos Reis ${ }^{3}$ por parte de mãe. Em 1830, mudou-se com a família para a Vila de São José de Guimarães, no continente, município de Viamão. Viveu parte de sua vida na casa de uma tia materna "melhor situada economicamente” (MOTT, 1988, p.61). Em 1847, concorreu à cadeira de Instrução Primária nessa localidade e, sendo aprovada, ali mesmo exerceu a profissão, como professora de primeiras letras, de 1847 a 1881 . Em 1880, fundou uma escola gratuita para crianças de ambos os sexos. Segundo Raimundo de Meneses, essa aula mista “escandalizou os círculos locais, em Maçaricó [...] e por isso foi a professora obrigada a suspendê-la depois de dois anos e meio.” (1978, p.570). Conforme afirmou Nascimento Morais Filho, a escola mista de Maria Firmina dos Reis era "uma revolução social pela educação e uma revolução educacional pelo ensino, o seu pioneirismo subversivo de 1880.” (1975, p. 310). O fato de ter fundado a primeira escola mista do país mostra as idéias avançadas de Maria Firmina para a época. Pense-se no tipo de educação que recebiam as meninas no século XIX: leitura, com o objetivo religioso, bordado, piano e para algumas o ensino do francês, língua da sociedade! Mas gostaria de destacar, como já o fiz em artigo anterior ${ }^{4}$, o pioneirismo de outra brasileira, desta vez, do extremo sul: Maria Josepha Pereira Pinto que também fundou uma escola mista, bem antes da maranhense. É uma lástima que não tenhamos encontrado quase nada dessa mulher pois foi pioneira em muitos aspectos, inclusive na fundação de um periódico, de cunho político de nome Belona irada contra os sectários de Momo.

Casou-se em Rio Pardo, em 1800, com Manuel Inácio Pereira Pinto $^{5}$, primeiro carcereiro da cadeia de Porto Alegre. Em seu trabalho, o marido deixou escapar um preso e respondeu a processo sobre o caso. Depois de condenado, desapareceu para sempre, deixando esposa e um casal de filhos: José Joaquim Barreto (Rio Pardo, 1802) e Engrácia Maria (Rio Pardo, 1804) ${ }^{6}$.

Depois desse acontecimento, Maria Josefa fundou uma escola primária mista que ficava em sua própria casa, situada à rua de Santa Catarina, hoje Dr. Flores, em Porto Alegre, segundo informações de um seu discípulo que ficou famoso, Antônio Alves Pereira Coruja ${ }^{7}$.

Anota ele em Antigualhas: “Abaixo da venda do Chico Cambuta na esquina da rua da Ponte seguia-se a meia-água em que a poetisa D. Maria Josefa tinha a sua escola de crianças de ambos os sexos, de que eu também fazia parte...” (1983, p.70). Neste livro, o Prof. Coruja faz algumas pequenas referências à Maria Josefa, nunca se esquecendo de mencioná-la como a poetisa. Já por esse tipo de menção, pode-se concluir que era muito conhecida na pequena cidade e que teve suas poesias declamadas. Uma outra
${ }^{3}$ Francisco Sotero dos Reis. S. Luís, MA, 1800-1871. Distinguiuse como gramático e filólogo. Lente de Latim e primeiro diretor do Liceu Maranhense. Fundou jornais. Autor do Curso de Literatura Portuguesa e Brasileira, 1867-1873, muito citado e consultado à época. Mas é claro que sua obscura prima aí não teve entrada!

${ }^{4}$ In: Escritoras

brasileiras do século XIX - antologia. Conforme nota número 1.

${ }^{5}$ Nascido em Porto Alegre em 1773 e falecido em 1830.

${ }^{6}$ Em Antônio Alves Coruja, lê-se o seguinte sobre a Cadeia da Justiça: "Foi seu primeiro carcereiro Manuel Inácio Barreto, marido da poetisa Maria Josefa, o qual tendo de sofrer uma pena por erro de ofício, desapareceu para sempre, deixando um casal de filhos e sua mulher que arrastou o resto de seus dias como viúva incerta”. (1983, p 127).

${ }^{7}$ Antônio Álvares Pereira Coruja nasceu em Porto Alegre em 1806 e faleceu no Rio de Janeiro em 1889. Cursou as aulas primárias de Maria Josefa e de Antônio D’Ávila, o “Amansa-burros”. Ficou muito conhecido como professor, autor de livros didáticos, pesquisador de história e organizador de associações civis. Publicou várias séries de reminiscências, intituladas Antigualhas, divulgadas pelo Anuário do Rio Grande do Sul, organizado pelo Dr. Graciano Alves de Azambuja. A edição por mim consultada é, segundo o organizador, o texto integral dessas memórias. 
referência interessante de Coruja é a comparação que faz entre os honorários de um professor, o Amansa (Professor Antônio d'Ávila, vulgo Amansa-burros) e Maria Josefa: "Esqueci-me de dizer no lugar competente, que o Amansa [...] recebia como honorário duas patacas por mês, ao passo que a poetisa D. Maria Josefa se contentava com uma pataca só!” (1983, p.70). Embora o escritor não analisasse as razões de tal fato, fica claro que, desde as mais remotas origens aqui no Brasil as professoras — mulheres - sempre receberam menos por idêntico trabalho de seus colegas! (1983, p.70).

Voltando ao tema do presente artigo, em 1880, Maria Firmina conquistou o primeiro lugar em História da Educação Brasileira, o que lhe valeu o título de Mestra Régia, segundo informa a pesquisadora Maria Lúcia de Barros Mott (1988, p.62). Em 1881, mesmo aposentada do ensino público oficial, continuou ensinando no povoado de Maçaricó a filhos de lavradores e de fazendeiros demonstrando sua vocação primeira: a de mestra.

Hoje, em virtude do Movimento Negro, há um renascimento dos estudos sobre a narrativa de Maria Firmina, mas isso também se deve à linha de pesquisa "Mulher e literatura” do Grupo de Trabalho "A mulher na literatura”, da ANPOLL (Associação Nacional de Associação Nacional de Pós-Graduação e Pesquisa em Letras e Lingüística), que realizou um trabalho de resgate importante em torno das escritoras do século XIX. Ao lado do crescimento de associações negras, organizações não-governamentais (ONG’s) e movimentos de resistência, há também o aparecimento de uma intelectualidade negra e o surgimento de periódicos e livros que vão fazendo surgir a produção literária dessa intelectualidade.

A produção literária dos afro-descendentes encontra nas últimas décadas
uma atenção mais singularizada por parte de escritores e críticos que bus-
cam mapear uma tradição negra vernacular no âmbito da Literatura Brasi-
leira, sublinhando o diverso leque de matizes e linhagens que traduzem a
afrodescendência, caligrafada na e pela letra literária. A expansão do olhar
sobre textos, autores, temas, situações e experiências, de certa forma até
então exilados da reflexão crítica, dos meios e circuitos de veiculação e
de reconhecimento, distende nossa cartografia literária e desafia as redes
discursivas formadoras de juízo e de opinião. (MARTINS, 2010).

Um dos primeiros trabalhos sobre literatura negra no Brasil foi do inglês David Brookshaw, Raça e cor na literatura brasileira, de 1983. E especificamente sobre a literatura das mulheres negras, salienta-se o de Maria Lúcia de Barros Mott, Escritoras negras: resgatando a nossa história, de 1989, um marco de relevância nesses estudos, reivindicando nomes, numa tradição afro-brasileira, como os de Rosa Maria Egipcíaca de Vera Cruz, Teresa Margarida da Silva e Orta, Maria Firmina dos Reis, Luciana de Abreu, Auta de Souza, Antonieta Barros e outros. 
No século XIX, tivemos vários escritores negros, alguns com plena consciência do racismo, como Cruz e Sousa, outros que venceram e conseguiram sobressair-se numa sociedade branca, como Machado de Assis, e algumas escritoras negras que ficaram esquecidas, tal como as brancas.

O romance de Maria Firmina foi descoberto, em 1962, em um “sebo", no Rio de Janeiro, por Horácio de Almeida, que, depois de pesquisa, identificou o pseudônimo da romancista maranhense e fez uma fac-similar do texto ${ }^{8}$. No prólogo a esta edição, Horácio de Almeida salienta a ausência da escritora nos estudos críticos dedicados à literatura maranhense. O único autor a mencioná-la foi Sacramento Blake (1970, p.232).

Maria Firmina deixou um álbum de recordações publicado por Nascimento Filho, na reunião de textos que fez em 1975, que foi escrito, aparentemente, a partir de 1853, visto ser essa a data do primeiro texto. Digo aparentemente, porque a publicação contempla só uma parte dos manuscritos de Maria Firmina, os quais tendo sido deixados com um filho adotivo, foram dele roubados. Informou o Sr. Leude Guimarães ao pesquisador Nascimento Morais Filho o seguinte:

Quando vim para São Luís, depois de sua morte, trouxe muitos manuscritos seus. Eram cadernos com romances e poesias e um álbum onde havia muita coisa de sua vida e da nossa família. Mas os ladrões, um dia, entraram no quarto do hotel onde estava hospedado, arrombaram o baú, e levaram tudo o que nele havia. Só me deixaram, de recordação, os restos desse álbum, que encontrei pelo chão! (1975, p. 211).

O “Álbum” é composto de pequenos textos, a maioria versando sobre a dor da partida: seja pela morte, seja pela mudança de Guimarães para outra cidade. De qualquer modo, os textos expressam a tristeza da separação. Imaginando-se as distâncias e os meios de transporte da época, pode-se perceber que uma mudança de cidade equivalia muitas vezes a uma despedida para sempre.

O tom que domina o “Álbum” é o elegíaco e, dentre as lamentações, encontram-se dados que nos permitem concluir que a vida de Maria Firmina foi árdua e solitária. O “Álbum” tem também teor de diário íntimo com anotações não só dos seus estados d' alma, mas ainda de pequenos fatos como, por exemplo, em 11 de janeiro de 1860, mudou-se de casa, em 1862, adotou um órfão, recém-nascido que faleceu um ano depois e, assim por diante.

Mas o texto mais interessante, para o conhecimento da escritora, é o intitulado "Resumo da minha vida" que, em tom evidentemente romântico e por demais melancólico, fala de sua infância e de sua solidão. Sobre a educação recebida, é muito curioso o trecho abaixo, que demonstra, com
${ }^{8}$ [REIS, Maria Firmina dos]. Ursula, Romance original brasileiro, por Uma Maranhense. São Luís: Typographia Progresso, 1859. 199 p. Ed. fac-similar. Prefácio de Horácio de Almeida. Maranhão: Governo do Estado, 1975. Foi reeditado em 1988, pelo INL (Rio de Janeiro; Brasília), na Coleção Resgate (com introdução de Charles Martin e atualização e notas de Luiza Lobo) e em 2004, pela editora Mulheres (Florianópolis) (com atualização e posfácio de Eduardo de Assis Duarte). 
clareza, a plena consciência da escritora sobre os problemas da educação patriarcal:

De uma compleição débil e acanhada, eu não podia deixar de ser uma criatura frágil, tímida, e por conseqüência melancólica: uma espécie de educação freirática [grifo meu], veio dar remate a estas disposições naturais. Encerrada na casa materna, eu só conhecia o céu, as estrelas e as flores, que minha avó cultivava com esmero; talvez por isso eu tanto amei as flores; foram elas o meu primeiro amor. Minha irmã... minha terna irmã, e uma prima querida, foram as minhas únicas amigas de infância; e nos seus seios eu derramava meus melancólicos e infantis queixumes; por ventura sem causa, mas já bem profundos. [....] Vida!... Vida, bem penosa me tens sido tu! Há um desejo, há muito alimentado em minha alma, após o qual minha alma tem voado infinitos espaços, e este desejo insondável, e jamais satisfeito, afagado, e jamais saciado, indefinível, quase que misterioso, é, pois, sem dúvida, o objeto único de meus pesares infantis e de minhas mágoas. Eu não aborreço os homens, nem o mundo, mas há horas e dias inteiros, que aborreço a mim própria. (MORAIS FILHO, 1975, p.154-155).

O que é curioso observar, no texto acima, é, em primeiro lugar, a consciência dos limites da educação recebida. A escritora não afirma aqui que existam desigualdades entre meninos e meninas, mas fica bem claro que a "educação freirática” não foi bem aceita por ela. O que seria esse tipo de educação senão a educação da mulher voltada para os afazeres domésticos? Recebeu uma educação segregada e, por essa razão, quis ministrar uma educação diferente, dirigida a ambos os sexos, educados juntos. Outra questão que me parece importante nesse pequeno texto é o núcleo matriarcal em que viveu Maria Firmina. A casa não é paterna mas materna, ela não fala de nenhum homem, nem pai, nem avô nem irmãos, mas da avó, que cultiva flores e da irmã e da prima, amigas de infância:”...eu lembro esses dias de infância que passei no regaço de minha mãe, e entre folguedos tecidos por mim, e por minhas duas amigas...” Mas gostaria de assinalar que, apesar do isolamento, Maria Firmina deve ter recebido conhecimentos bem sólidos de parte do núcleo familiar, pois sabe-se que o ensino público e o particular no Maranhão eram muito precários e quase inexistente o ensino voltado às meninas (MOTT, 1989, p.61).

Maria Firmina dos Reis, em seu romance, segue os ditames do Romantismo, da narrativa sentimental. Mas o que nos interessa aqui é fundamentalmente refletir sobre o ponto de vista da autora, uma mulher negra, vivendo na época da escravidão no Brasil, no estado do Maranhão, tendo publicado ainda em pleno tempo de escravos. Este romance é considerado o primeiro romance abolicionista no Brasil, sendo anterior, portanto, ao fa- 
moso romance de Bernardo Guimarães, A escrava Isaura, publicado bem depois de Ursula, já em 1875.

Ao lado do amor entre os jovens protagonistas, Úrsula e Tancredo, a trama põe em cena, como personagens importantes, dois escravos que vão dar a nota diferente à narrativa, pois, pela primeira vez o escravo negro tem voz e, pela memória, vai trazendo para o leitor uma África outra, um país de liberdade. Repetindo palavras de Charles Martin, em sua análise introdutória à reedição do romance:

A luta psicológica dos personagens pela própria identidade supera as simples descrições de navios negreiros. A visão de Maria Firmina é bem mais ampla e refinada que em geral. Neste romance, ela escapa ao estereótipo da "mulata sensual” (como a Rita Baiana, de Aluísio Azevedo) como o principal ponto de interesse nos enredos sobre a raça negra. (1988, p.9).

O enredo é muito romântico, ligando-se ao veio que buscou inspiração num passado inexistente, medieval, à moda européia. Os temas são os do amor e morte, castigos e loucura. A autora também segue as regras do gênero romance do Romantismo: as personagens da trama central são jovens, belas, apaixonadas e brancas. A questão da escravidão só vai aparecer nas personagens secundárias que, hoje, por uma reviravolta teórica, tornaram-se dominantes nas análises. Com isso, quero destacar a importância que tomaram os estudos e resgates sobre a literatura negra entre nós, já tendo sido muito acentuados nos Estados Unidos há mais tempo. Isso talvez se deva a que a literatura negra americana, mesmo no século XIX, deixou abundante produção, inclusive entre as mulheres.

Maria Firmina dos Reis é mulata e tendo sofrido, seguramente, o preconceito racial vigente no Brasil, ainda assim escolhe o par romântico pertencente à etnia dominante. O racismo imperante é muito bem retratado em pinturas da época, além, naturalmente, de o ser na literatura. Schuma Schumaher cita o quadro do pintor espanhol Modesto Brocos y Gómez (1852-1936), A redenção de C $\tilde{a}^{9}$. Neste quadro, aparece retratada "uma senhora negra que levanta as mãos aos céus em sinal de gratidão e reconhecimento pela graça proporcionada pela divina bondade. Seu neto foi redimido, embranqueceu, pois sua filha, já miscigenada, casou com um homem branco”(SCHUMAHER, BRAZIL, 2007, p.35).

Para conhecermos o pensamento de Maria Firmina sobre a questão do negro, a resposta estará nas personagens negras de Úrsula. As que aparecem nos romances do século XIX são invariavelmente subalternas: amas-de-leite, como em A Familia Medeiros ou em A Silveirinha de Júlia Lopes de Almeida, e escravos, como em Úrsula.

Como analisa a pesquisadora Maria Consuelo Cunha Campos,

A romântica escrava - praticamente branca - Isaura, de Bernardo Guimarães, em aberto contraste com as demais personagens cativas do 
romance, estas, sim, negras; a sensual mulata Rita Baiana, do Aluísio de Azevedo naturalista de $O$ Cortiço, onde também encontramos a negra escrava Bertoleza, fugida de seu senhor, mas sempre trabalhando de sol a sol no estabelecimento com o companheiro branco: as donzelas casadouras alencarianas, todas eurodescendentes, são exemplos de representações de gênero e de relações raciais contemporâneas de uma política pública de branqueamento. (2008, p. 95-98).

Teríamos de chegar ao século XX para ter uma personagem como Clara dos Anjos, de Lima Barreto, a principal do romance de mesmo nome.

Conforme escreveu Maria Lúcia Mott:

É preciso lembrar da posição corajosa de Maria Firmina ao denunciar a ilegitimidade e violência da escravidão, justamente no Maranhão, província que era considerada como sendo fortemente escravista. $\mathrm{O}$ fato de o vilão da história, aquele que persegue a irmã, mata o cunhado e o pretendente da sobrinha, ser o pior e mais cruel dos senhores, não quer dizer que a escravidão seja legítima para os escravos que possuem um bom senhor. Túlio e Suzana, escravos de Luiza B., proprietária boa e compreensiva não aceitam sua condição de "míseros e cativos".

Maria Firmina situa-se ao lado daqueles autores que condenam a escravidão porque ela era contrária às leis de Deus, e que acreditavam que o negro, apesar dos anos vividos sob o cativeiro, não tinha perdido as suas qualidades naturais. Difere neste ponto de autores contemporâneos, como Macedo, que condenavam a escravidão, dentre outras razões, porque ela corrompia o escravo e conseqüentemente contaminava a família branca. (1989, p. 61).

A idéia de que os escravos contaminavam os brancos com suas maneiras, crenças e vícios, muito disseminada na época, é derivada da política de branqueamento, que se alimentava do biologismo do século XIX, classificando a variedade humana em raças superiores e inferiores. Já Montesquieu pensava que era prejudicial a escravidão para o escravo, mas, igualmente, para o dono. Algumas viajantes estrangeiras que estiveram no Brasil, no século XIX, como a Baronesa de Langsdorff e Mme. van Langendonck, também já traziam, antes mesmo de aqui conhecerem a escravidão, as mesmas idéias. Em vários diários dessas viajantes, a presença da escravidão é uma constante e ora teremos críticas, ora aceitação.

A viajante belga, Mme. van Langendonck, se depara com a escravidão, prática contra a qual reagira e até escrevera, na Europa, mas no Brasil, ao conviver com essa realidade, deixa transparecer os mesmos preconceitos dos escravocratas e demonstra idéias arraigadas de branca de classe média alta e religiosa. E em seu diário de viagem, encontramos uma certa intolerância racial ao analisar as relações entre homens e mulheres negros da perspectiva de sua classe, não conseguindo vê-los de outra maneira. 
Suas observações acerca dos escravos negros baseiam-se no que viu do relacionamento entre crianças negras e brancas. E a educação recebida como mulher, com todas as amarras e preconceitos, traduz-se no que escreve a respeito:

Em suma, a escravidão, tal como a vi no Brasil, me pareceu menos funesta aos negros que prejudicial à raça branca.

Quaisquer que sejam as causas disso, o fato é que os maus instintos inerentes à natureza do negro deixam nele bem pouco espaço para os sentimentos de probidade, de pudor e de moral. No entanto, é entre essas criaturas que os brasileiros deixam seus filhos chegarem à idade da razão: essas crianças são educadas com os negrinhos e brincam com eles, que, para algumas coisas, nunca são crianças.

Que os negrófilos europeus não se indignem com as minhas livres apreciações. Mais do que qualquer um deles, indignei-me, de longe, contra a escravidão. Enderecei em prosa e em verso aos proprietários de escravos epístolas enternecedoras. Minha simpatia pelo povo negro era profunda, eu me compadecia deste, censurava os brancos, com confiança, e certamente não foi sem combate que renunciei a minhas convicções.

Mas depois vi de perto os negros, eu os vi dos dois sexos em diferentes condições e estou firmemente persuadida de que sua moralização, se não é impossível, exigiria vários séculos de esforços. (LANGENDONCK, 2002, p. 41).

Maria Firmina dos Reis vai se inspirar na idéia do "bon nègre” que, tal como o "bon sauvage” também nasceu na França. É importante notar que, além de dar voz ao negro em seu romance, a escritora maranhense segue o caminho traçado pela literatura ocidental com o romance Oroonoko, primeiro romance da escritora inglesa Aphra Behn (1999). Segundo a pesquisadora cubana Nara Araújo, a tipologia do "bon nègre” se consolida com este romance, um dos mais lidos na França, no século XVIII: “Oroonoko fijó el modelo para el bon nègre de la literatura francesa posterior” (1998, p. 104).

Também no romance de Maria Firmina dos Reis as personagens negras são cumpridoras dos deveres para com seus senhores, são leais e honestas. Podemos perguntar-nos se Maria Firmina dos Reis teria lido a escritora americana Harriet Beecher Stowe e seu conhecidíssimo romance A cabana do Pai Tomás, que fez bastante sucesso no Brasil...

A questão da Abolição vai ser quase um leit-motiv da pena feminina e isso tanto no Brasil como em outros países. Na França, por exemplo, com Olympe de Gouges, Germaine de Staël, la duchesse de Duras, Marceline Desbordes-Valmore e, na Inglaterra, com Aphra Behn - todas escritoras brancas e da classe alta. Somente com Úrsula teremos uma visão diferente do problema. A autora escreveu de acordo com a consciência possível para a época. E conferiu grande importância às personagens negras escravas, 
além de uma forte voz à escrava Mãe Susana, que é quem vai falar das memórias de sua amada África, uma terra de liberdade. A fala de Mãe Susana é realmente um dos pontos altos do romance e o tom de paixão, saudade e dor que transparecem deste texto bem mostram o engajamento de Maria Firmina na defesa do negro.

Mas, importa ainda notar que, além de dar voz ao negro, Maria Firmina adota o já referido modelo do "bon nègre", o "negro de alma branca”. Enquanto outros escritores que escreveram sobre a escravidão o fizeram de fora, com um olhar neutro, ela, Maria Firmina, em cujas veias corria o sangue de ancestrais africanos, escreve de dentro, como um deles. Por tal razão, a voz negra é tão forte neste romance e tão verossímil, pois a autora privilegia a identidade com a cultura negra, com a camada dos despossuídos. Não escreve um romance para negros, mas esforça-se por ascender socialmente à classe letrada do Maranhão e deseja realizar uma literatura que se inclua na chamada literatura erudita para que seu nome não seja esquecido.

No século XIX, a imagem do negro na literatura era a do escravo maltratado, submisso ou louco. Podem ser citados alguns exemplos em contos, como “A escrava”, da própria Maria Firmina dos Reis (2004, p. 241-262), ou “O tio Job” (2009, p.1070-79), de Ridelina Ferreira (186718??), ou no romance, como A família Medeiros (2009), de Júlia Lopes de Almeida (1862-1934), citando somente escritoras mulheres.

Ao ler os textos de mulheres negras, nota-se que a dominante é ainda a de literatura de testemunho. A voz negra se inicia, pois, com Maria Firmina dos Reis, na denúncia dos males da escravidão. É ela quem, pela primeira vez, na literatura brasileira, dá a voz ao negro. Não é a primeira vez que um/a autor/a inclui escravos negros em sua narrativa, mas é a primeira vez em que os negros têm voz. Essa voz trará uma África desconhecida do branco da Corte, como um continente de liberdade.

Depois de Maria Firmina e sua voz de resistência, devemos registrar outro grande poeta negro, revoltado e resistente, que foi o catarinense Cruz e Sousa. Conforme assinala o Professor Alfredo Bosi, com muita pertinência:

No mesmo Brasil culto do final do século XIX, em que Nina Rodrigues e seus discípulos na área de Medicina Legal apontavam a degenerescência das populações de origem africana, um poeta negro retinto, neto de escravos, filho de forros, João da Cruz e Sousa, acusava "a ditadora ciência d'hipóteses” de negar à sua raça "as funções do Entendimento e, principalmente do entendimento artístico da palavra escrita”

Compondo a prosa poética do Emparedado, que fecha o livro das Evocações, foi possível a Cruz e Sousa lançar o seu protesto contra os argumentos da ideologia dominante no discurso antropológico. Trata-se de um fenômeno notável de resistência cultural pelo qual o drama de uma existência, 
que é subjetivo e público ao mesmo tempo, sobe ao nível da consciência inconformada e se faz discurso, entrando assim, de pleno direito, na história objetiva da cultura. (2002, p.238).

Tanto Maria Firmina como Cruz e Sousa lançam apaixonados libelos. A escritora, pela voz dos oprimidos como Mãe Susana e Túlio. Já Cruz e Sousa, em sua poesia, em sua narrativa ou texto sobre o abolicionismo, fala de si próprio. A escritora, porém, não ousa incluir uma personagem principal como negra, enquanto o poeta, sob o manto da poesia, luta contra o racismo de maneira contínua e forte.

Na literatura negra pioneira, uma literatura de testemunho, não há primordialmente preocupação com o estético. Por isso, muitos desses textos ficaram esquecidos e negligenciados, pois trazem em alto grau um tom de agravo pessoal frente às inúmeras injustiças que sofreram. São textos que traduzem uma experiência de marginalização e exclusão social e, ao estudá-los devemos ter sempre em mente essas razões profundas para não julgá-los pelo estilo, pela preocupação estética: são os textos primeiros, os desbravadores ${ }^{10}$.

Pela leitura de sua obra e por depoimento, escrever foi a própria vida para Maria Firmina dos Reis. Escreveu sempre e abundantemente. É provável que não tenhamos nem a metade dos textos que essa mulher confiou às páginas de cadernos e blocos. Foi uma mulher sozinha, amou e não foi correspondida (LOBO, 1993, p. 222-235). Generosa, adotou várias crianças e deixou também muitos filhos espirituais, entre seus incontáveis alunos. Foi mestra e escritora.

No prólogo de Maria Firmina dos Reis ao romance Úrsula (1859), os topoi da modéstia são numerosos. O livro é “mesquinho e humilde”, é “pobre avezinha silvestre”, “tímida e acanhada”, sem dotes da natureza... Mas traz uma frase importante, chave para o entendimento da autora:

Sei que pouco vale este romance, porque escrito por uma mulher, e mulher brasileira, de educação acanhada e sem o trato e conversação dos homens ilustrados [...] com uma instrução misérrima [...] e pouco lida, o seu cabedal intelectual é quase nulo. (2004, p.13).

Como se lê neste livro de Maria Firmina, já aparecem alguns princípios que nortearão a crítica feminista, no século XX. O reconhecimento e o resgate das pioneiras não se dará pelas qualidades estéticas dos livros. Não serão comparadas às “grandes obras”, dos homens da mesma época, mas como livros de mulheres que não puderam ter a mesma educação. Mulheres para quem estavam fechadas as portas das instituições e o convívio com pensadores ilustres. Tais livros são estudados e resgatados como válidos porque primeiras manifestações de mulheres brasileiras. E é sobre isso que trata Maria Firmina dos Reis. Ela estabelece, com clareza, os limites
${ }^{10}$ Um estudo realizado pelo Grupo de Estudos em Literatura Brasileira Contemporânea, coordenado pela professora Regina Dalcastagnè, mostrou o verdadeiro racismo oculto que existe na literatura brasileira. O estudo realizado na Universidade de Brasília-UnB abrangeu o período de 1900 a 2004 e revelou uma ausência das mulheres negras nos romances brasileiros publicados nas três principais editoras do país: Record, Rocco e Companhia das Letras. Das 1.245 personagens catalogadas, apenas 34 são mulheres negras.

Destas, quase $70 \%$ ocupam papéis de domésticas, prostitutas, donas de casas, escravas ou bandidas.

A pesquisa analisou 256 obras e apenas $2,7 \%$ incluía uma mulher negra na história. Do total de obras analisadas, em apenas três situações elas foram protagonistas da história, no entanto, em apenas um romance, a narradora foi uma mulher negra. A coordenadora do estudo ressalta a importância das mulheres negras terem voz na literatura: “Quando uma personagem fala, ela adquire poder, faz com que o leitor siga pela perspectiva da mulher negra”. O estudo mostrou também o caráter dominante nos personagens da literatura brasileira. Mais de $70 \%$ dos personagens analisados nas mesmas obras eram homens brancos de classe média, 
aos quais estavam confinadas as mulheres do tempo e tem nítida noção da importância da educação, das vivências e das oportunidades culturais. Ao final do prefácio, no último parágrafo, Maria Firmina dos Reis expõe seus objetivos. Se o livro for amparado pela crítica, talvez sua autora publique livros melhores. Ou então, idéia bem interessante, talvez outras mulheres “com educação mais acurada, com instrução mais vasta e liberal” igualmente publiquem livros. A mesma idéia do "amparo da crítica” aparece no prólogo de Indígena do Ipiranga (pseudônimo de Ana Luiza de Azevedo Castro) ao seu D. Narcisa de Villar.

\section{Referências}

ALMEIDA, Horácio de. Prólogo. Úrsula. Ed. fac-símile. Maranhão: Governo do Maranhão, 1975. p. i-viii.

ALMEIDA, Júlia Lopes de. A família Medeiros. Atualização e fixação do texto por Marco Antonio Toledo Neder e introdução de Norma Telles. Florianópolis: Mulheres, 2009.

ARAÚJO, Nara. Visión romântica del outro: estúdio comparativo de Atala y Cumanda, Bug-Jargal y Sab. México: Universidad Autónoma Metropolitana, 1998.

B. A. Dedicação de uma amiga. Niterói: Typographia Fluminense de Lopes e Cia, 1850.

BEHN, Aphra. Oroonoko ou o escravo real. Romance. Tradução e introdução de Élvio A. Funck. Florianópolis: Mulheres, 1999.

BLAKE, Augusto Victorino Sacramento. Diccionário bibliographico brazileiro. Ed. fac-símile. Brasília: Conselho Federal de Cultura, 1970. v. 6, p. 232.

BOSI, Alfredo. Poesia versus racismo. Estudos Avançados, São Paulo, v.16, n.44, p.235-253 Jan./Apr., 2002.

BROOKSHAW, David. Raça e cor na literatura brasileira. Porto Alegre: Mercado Aberto, 1983.

CAMPOS, Maria Consuelo Cunha. Representações da mulher negra na literatura brasileira. In: SACRAMENTO. Sandra. Gênero, identidade e hibridismo cultural: enfoques possíveis. Ilhéus: Editus, 2009. p. 95-98.

CORUJA, Antônio Alves. Antigualhas, Reminiscências de Porto Alegre. Introdução e notas de Sérgio da Costa Franco. Porto Alegre: ERUS Companhia União de Seguros Gerais, 1983.

CRUZ E SOUSA, João da. Obra completa. Organização de Andrade Muricy. Rio de Janeiro: Aguilar, 1961. heterossexuais e de nível superior. "É uma ilusão que a literatura seja um objeto artístico muito crítico. Ela é produzida por uma elite branca, que reflete suas representações, assim como o cinema, o teatro", afirma a pesquisadora. A ausência das mulheres negras na literatura não é apenas uma característica da literatura do período analisado, como foi mostrado no estudo, mas um pequeno panorama de uma literatura oficialista, racista e comercial dominada pela ideologia burguesa que se perpetua desde os tempos de escravidão. V. <http:// www.pco.org.br/ conoticias/ler_materia. php?mat=12890>. Acesso: 20/10/2009. 
FERREIRA, Ridelina. O tio Job. A Mensageira, v. II, p. 51-58. Republicado em Escritoras brasileiras do século XIX: antologia. Florianópolis: Mulheres, 2009. v. 3. p. 1070-79.

LAJOLO, Marisa. Como e por que ler o romance brasileiro. Rio de Janeiro: Objetiva, 2004.

LANGENDONCK, Madame van. Uma colônia no Brasil. Tradução de Paula Berinson. Introdução de Augusto Meyer. Florianópolis: Mulheres, 2002.

LANGSDORFF, Baronesa E. de. Diário de sua viagem ao Brasil, 18421843. Tradução de Patrícia Chittoni Ramos e Marco Antônio Toledo Neder. Introdução de Míriam Lifschitz Moreira Leite. Florianópolis: Mulheres, 1999.

LOBO, Luiza. Auto-retrato de uma pioneira abolicionista. Crítica sem juízo. Rio de Janeiro: Francisco Alves, 1993. p. 222-238.

MARTIN, Charles. Uma rara visão de liberdade. In: REIS, Maria Firmina dos. Úrsula. 3 ed. Rio de Janeiro: Presença, 1988. p. 9-14.

MARTINS, Wilson. História da Inteligência brasileira. São Paulo: Cultrix, 1977. v. 3.

MARTINS, Leda. A fina lâmina da palavra. Disponível em: http://www. letras.ufmg.br/poslit Acesso em: 11/fev/10.

MENESES, Raimundo de. Dicionário literário brasileiro. 2. ed. rev., aum. e atual. Rio de Janeiro: Livros Técnicos e Científicos, 1978. p. 570571.

MORAIS FILHO, Nascimento. Maria Firmina dos Reis: fragmentos de uma vida. Maranhão: Imprensa do Governo do Maranhão, 1975.

MOTT, Maria Lúcia de Barros. Submissão e resistência: a mulher na luta contra a escravidão. São Paulo: Contexto, 1988.

Escritoras negras: resgatando a nossa história. Rio de Janeiro: CIEC/UFRJ, 1989. (Coleção Papéis Avulsos).

MUZART, Zahidé Lupinacci (Org). Escritoras Brasileiras do Século XIX: Antologia. Ed. Mulheres/Edunisc, 2000.

[REIS, Maria Firmina dos]. Ursula, Romance original brasileiro, por Uma Maranhense. São Luís: Typographia Progresso, 1859. 199 p. Ed. fac-similar. Prefácio de Horácio de Almeida. Maranhão: Governo do Estado, 1975. [Reeditado em REIS, Maria Firmina dos. Úrsula. Introdução de Charles Martin e atualização e notas de Luiza Lobo. Rio de Janeiro; Brasília: INL, 1988. (Coleção Resgate); e em REIS, Maria Firmina dos. Úrsula. Atualização e posfácio de Eduardo Assis Duarte. Florianópolis: Mulheres, 2004. 
REIS, Maria Firmina dos. A escrava. Conto. A Revista Maranhense, n. 3, 1887. [Republicado em MORAIS FILHO, Nascimento. Maria Firmina: fragmentos de uma vida. Maranhão: Imprensa do Governo do Maranhão, 1975; e em REIS, Maria Firmina dos. Úrsula. Florianópolis: Mulheres; Editora PUC-Minas, 2004. p. 241-262.]

SCHUMAHER, Schuma; BRAZIL, Érico Vital. Mulheres negras do Brasil. Rio de Janeiro: SENAC, 2007.

TELLES, Norma. Encantações: escritoras e imaginação literária no Brasil século XIX. São Paulo: Intermeios, 2012 (Coleção Entregêneros).

Recebido em 17/10/2013

Aprovado em 08/02/2014 